\title{
Partial replacement of sand with marble waste and scoria for normal strength concrete production
}

\author{
Begashaw Worku Yifru' ${ }^{1}$. Bahiru Bewket Mitikie $^{2}$
}

Received: 20 June 2020 / Accepted: 14 October 2020 / Published online: 2 November 2020

(c) Springer Nature Switzerland AG 2020

\begin{abstract}
Sand is used more than any other natural resources except water and air, However, it's extracted at a rate far greater than it's renewal. The availability of sand in the growing demand of the construction industry will be a challenge due to a wide range of variability, cost, and, quality problems. This study aims to investigate normal strength concrete by partially replacing sand with marble waste and scoria. Experimental investigations were conducted to study the chemical, physical, mechanical and fresh property of concrete containing marble waste and scoria. Marble: scoria ratios of 2:1, 1:1, and 1:2 was used and then the combined fraction of both marble waste and scoria in concrete was increased from 33 to 67 and $100 \%$. Chemical analyses of the marble waste show that it is mainly composed of $\mathrm{CaO}$ and $\mathrm{SiO}_{2}$, whereas scoria is composed of $\mathrm{SiO}_{2}, \mathrm{Al}_{2} \mathrm{O}_{3}, \mathrm{Fe}_{2} \mathrm{O}_{3}, \mathrm{CaO}$, and $\mathrm{MgO}$. Concrete containing marble waste and scoria as a sand replacement shows better compressive strength than the conventional concrete but the workability and compressive strength decrease with an increase in the content of marble waste and scoria. Cost analyses indicate that concrete containing marble waste and scoria can save up to $4.5 \%$ of the total cost of concrete with weight reduction up to $5 \%$ and the optimum replacement level is $22.5 \%$ marble waste and $44.5 \%$ scoria.
\end{abstract}

Keywords Normal concrete · Sand · Crushed marble waste · Scoria · Cost analysis · Workability $\cdot$ Compressive strength

\section{Introduction}

Global production of concrete is about 12 billion tons a year corresponding to almost $1 \mathrm{~m}^{3}$ per person per year making it one of the largest users of natural resources in the world [1]. It is predicted that concrete usage will increase to more than 7.5 billion $\mathrm{m}^{3}$ (about 18 billion tons) a year by 2025 [2].

Recently, the increasing consumption of concrete by the construction industry has led to the rapid depletion of natural sand and good quality of sand is not readily available in most areas of Ethiopia [3]. It must be transported a long distance or contractors use whatever sand is available, which might not meet the necessary standards.
Therefore, it is necessary to find a locally abundant supply of natural material or industrial wastes as a substitute. On the other hand, a significant amount of waste is generated with an increase in production, and this waste negatively affects the environment [4]. Hence, instead of producing aggregates and minerals from virgin sources, it is more than appropriate to use waste by-products from industries and locally abundant natural materials.

Marble is one of the largest produced natural stones in the world and it accounts for $50 \%$ of the world's natural stone production [5]. The production of marble waste is estimated at around 3 million tons annually. Marble production generates $20-30 \%$ waste or more because of its irregular shape, smaller in size, cutting, and polishing

\footnotetext{
$\triangle$ Bahiru Bewket Mitikie, bahirdire@gmail.com; Begashaw Worku Yifru, begashaw.worku@bdu.edu.et; Begashawworku20@gmail.com | 'Department of Civil Engineering, Bahir Dar Institute of Technology, Bahir Dar University, Bahir Dar, Ethiopia. ${ }^{2}$ Department of Civil Engineering, Adama Science and Technology University, P.O. Box 1888, Adama, Ethiopia.
} 
process depending upon type, quarrying, and processing method implemented. The waste may be as high as $60 \%$ [6]. The marble industry contributed to so many environmental issues due to marble waste production in the process of mining and sawing. Thus, the usage of waste marble in concrete production may be an important step toward sustainable development $[7,8]$.

Ethiopia is the 4th leading producer of pumice and scoria aggregate in the world following Italy, Chile, and Ecuador [9]. Scoria is abundantly found especially in the main ethiopian rift valley (MER) and around Bahir Dar, however, it's used is limited to a base course in road construction and production of hollow concrete blocks [10]. This is due to the lack of confidence in using the material in concrete for structural purposes [11]. However, these locally available materials have not been tested and approved for use widely in the Ethiopian construction industry.

Previous researchers conducted a variety of studies on marble waste and scoria as substitutions for cement, coarse aggregate, and fine aggregate individually, but no research has been done by combining both marble waste and scoria. Scoria is known to reduce workability, because of its porosity. Marble waste meanwhile has less of water demand (especially up to $75 \%$ replacement), so by combining the two the reliance on conventional coarse and fine aggregate can be reduced, while reducing the selfweight of the concrete (from the scoria), without increasing water demand too greatly (by using marble waste).

This research is undertaken to investigate the workability, strength, and cost of normal strength concrete by partially replacing sand with marble waste and scoria. In this study, the chemical characteristics of marble waste and scoria, the result of an experimental investigation of strength, and the workability of concrete containing marble waste and scoria are presented.

\section{Materials and methods}

\subsection{Materials}

All materials used in the investigation were extracted from quarries near Bahir Dar, Ethiopia. The cement used is an ordinary portland cement (OPC) with a grade of $42.5 \mathrm{R}$ from Dangote Cement Factory and potable tap water was employed for all mixes. The marble waste (Fig. 1) was taken from a factory in which, the raw materials come from Mamkush, Ethiopia which is located $350 \mathrm{~km}$ away from the factory. After all, the jaw crusher has crushed the marble waste scrap to fulfill the ASTM C 136 gradation of fine aggregate.

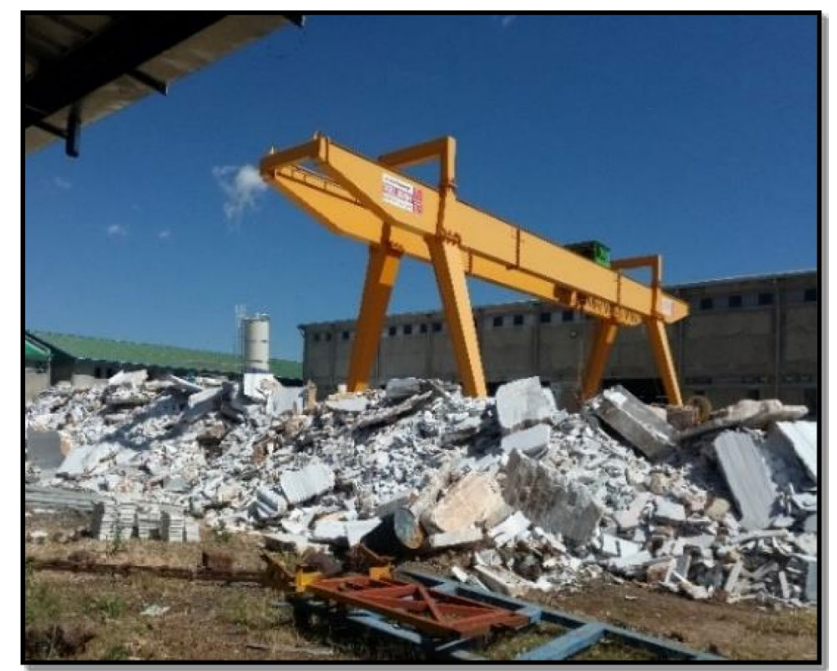

Fig. 1 Marble scrap and its accumulation at the factory

\subsubsection{Sand}

Rocks are naturally occurring crystalline, cemented, or consolidated materials that form the immediate crust. They are subdivided into types according to mineralogical, petrological, and physical characteristics [12]. Almost allnatural aggregate materials originate from bedrocks. There are three kinds of bedrocks namely; igneous, sedimentary, and metamorphic [13].

Sand is a naturally occurring granular material composed of finely divided rock and mineral particles. It is defined by size, being finer than gravel and coarser than silt. Sand can also refer to a textural class of soil or soil type; i.e., a soil containing more than $85 \%$ sand-sized particles (by mass) [14]. Sand develops naturally by weathering particles of rocks resulting in various grades and sizes depending upon the amount of wearing [15]. Fine aggregates generally consist of natural sand or crushed stone with most particles smaller than $5 \mathrm{~mm}$ (0.2 in.) [16], the lower size limit of about $0.07 \mathrm{~mm}$, or a little less [17].

The most common component of sand is quartz. Quartz is a mineral that is abundant, hard, nearly insoluble in water, and resistant to chemical decay. Other sands are made of silicates such as feldspar. The quartz sands usually contain a small quantity of feldspar and white mica. Yellow, brown, and red sands contain iron compounds [18].

\subsubsection{Impacts of natural sand mining Mineral aggregates} are the most mined materials in the world with extraction sites located near virtually every city and town. it's estimated that between 32 and 50 billion tons of aggregates (sand and gravel) are extracted each year globally [19].

Sand mining is a direct cause of erosion and also impacts the local wildlife. Disturbance of underwater 
and coastal sand causes turbidity in the water, which is harmful to such organisms as corals that need sunlight. It also destroys fisheries, causing problems for people who rely on fishing for their livelihoods. Excessive instream sand-and-gravel mining causes the degradation of rivers. In-stream mining lowers the stream bottom, which may lead to bank erosion. Depletion of sand in the streambed and along coastal areas causes the deepening of rivers and estuaries, and the enlargement of river mouths and coastal inlets [20].

In-stream sand mining results in the destruction of aquatic and riparian habitat through large changes in the channel morphology. Impacts include bed degradation, bed coarsening, lowered water tables near the streambed, and channel instability. It is also a threat to bridges, riverbanks, and nearby structures [21].

2.1.1.2 Property of sand According to ASTM C33, aggregates that are less than $4.75 \mathrm{~mm}$ are designated as fine aggregate. For this study, locally available well-graded river sand free from deleterious materials used as a fine aggregate. Various tests were performed to investigate the quality of the fine aggregate as per the ASTM standard. Figure 2 shows the gradation of sand.

The sand used for the study has the following properties.

\begin{tabular}{ll}
\hline Fineness modulus & 2.63 \\
Unit weight & $1685 \mathrm{~kg} \mathrm{~m}^{3}$ \\
Specific gravity & 2.61 \\
Absorption & $4 \%$ \\
Free moisture content & $3.5 \%$ \\
Silt content & $2.6 \%$ \\
\hline
\end{tabular}

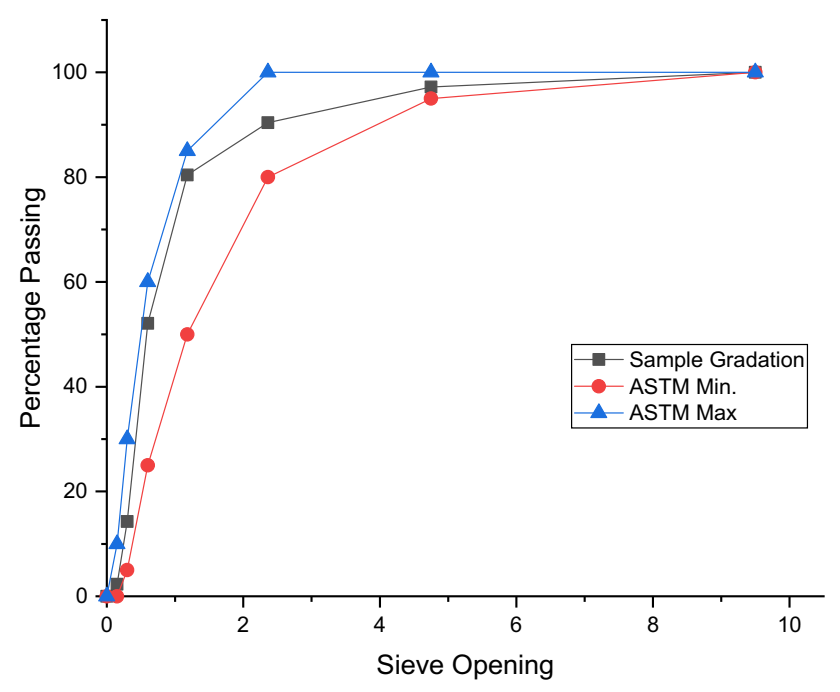

Fig. 2 Grading of sand

\subsubsection{Marble}

As per ASTM, standard C294-05 Marble is defined as a recrystallized medium-to coarse-grained carbonate rock composed of calcite or dolomite, or calcite and dolomite. The original impurities are present in the form of new minerals, such as micas, amphiboles, pyroxenes, and graphite. Chemically, marble is a crystalline rock composed predominantly of calcite, dolomite, or serpentine minerals. The other mineral constituents vary from origin to origin. Quartz, muscovite, tremolite, actinolite, micro line, chert, talc, garnet, osterite, and biotite are the major mineral impurities whereas $\mathrm{SiO}_{2}$, limonite, $\mathrm{Fe}_{2} \mathrm{O}_{3}, \mathrm{Mn}$, and $\mathrm{FeS}_{2}$ are the major chemical impurities associated with marble [22].

2.1.2.1 Impact of marble waste on the environment The marble industry produces a large amount of waste during mining and processing stages. This waste is dumped on open land, which creates a lot of environmental as well as health problems.

The following environmental damage might occur. The porosity and permeability of topsoil are reduced tremendously, the fine marble particles with high $\mathrm{pH}$ reduce the fertility of the soil, causing air pollution, corrode nearby machinery, depletes natural resources in terms of wastewater, marble, small pieces of marble, erosion of top fertile soil cover, contamination of the rivers and other water, vibrations and noise effects which, associated with quarry operations of drilling and blasting [23].

2.1.2.2 Property of crushed marble waste Similar procedures with sand were followed to determine the physical properties of marble waste since marble waste categorized under normal weight aggregate based on its density $\left(1670 \mathrm{~kg} / \mathrm{m}^{3}\right.$ which ranges between 1280 and $1920 \mathrm{~kg} /$ $\mathrm{m}^{3}$ ) and the marble scrap crushed into fines to fulfill the ASTM fine aggregate requirement. Figure 3 shows the gradation of crushed marble waste.

The marble waste used for the research has the following properties.

\begin{tabular}{ll}
\hline Fineness modulus & 2.72 \\
Unit weight & $1670 \mathrm{~kg} / \mathrm{m}^{3}$ \\
Specific gravity & 2.72 \\
Absorption & $7.2 \%$ \\
Free moisture content & $3.5 \%$ \\
Silt content & $3.4 \%$ \\
\hline
\end{tabular}

\subsubsection{Scoria}

As per ASTM, standard C294-05 scoria is defined as a darkcolored coarsely vesicular type containing more or less 


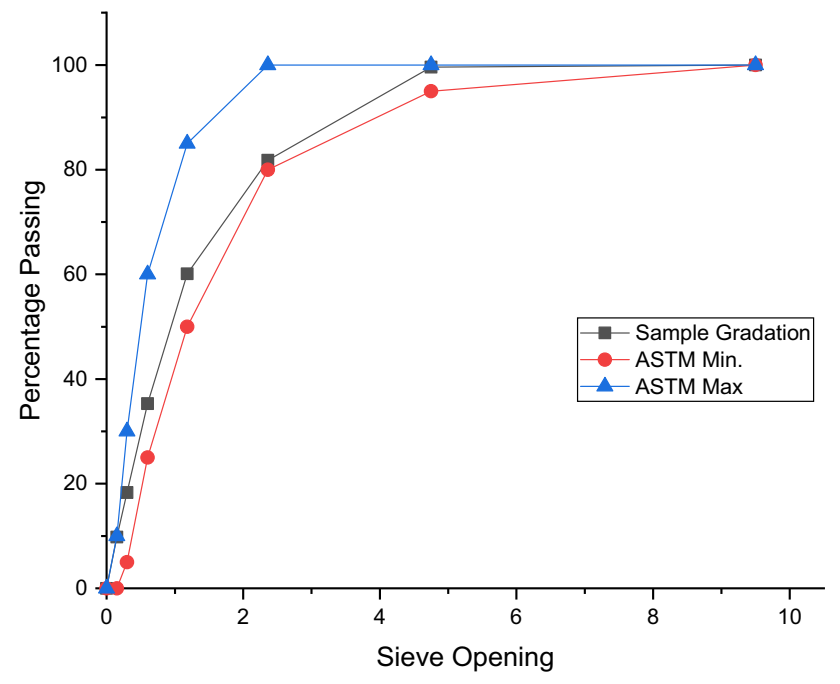

Fig. 3 Grading for crushed marble waste

spherical bubbles, it is a volcanic glass of igneous rock composed of wholly of glasses are named based on their texture and internal structure. Scoria is a volcanic cinder, which generally has a rough surface and highly porous nature, with its pores chiefly in the form of vesicles instead of the more tube-like, interconnected pores of the pumice [11].

The chemical and Mineralogical composition of volcanic scoria varies widely and depends on its source. Owing to their formation process scoria, volcanic scoria consists of crystalline and non-crystalline particles as glassy particles [24]. Scoria is particularly rich in $\mathrm{SiO}_{2}, \mathrm{Al}_{2} \mathrm{O}_{3}$. It also contains other oxides such as $\mathrm{K}_{2} \mathrm{O}, \mathrm{Na}_{2} \mathrm{O}, \mathrm{Fe}_{2} \mathrm{O}_{3}, \mathrm{CaO}, \mathrm{MgO}$, $\mathrm{SO}_{3}, \mathrm{MnO}, \mathrm{P}_{2} \mathrm{O}_{5}, \mathrm{H}_{2} \mathrm{O}$, FeO, etc. Physically, scoria (lapilli) ejected during basaltic eruptions vary considerably in its vesicularity, but densities are much greater than those pumice materials. Usually, the bulk unit weight of scoria is less than $1120 \mathrm{~kg} / \mathrm{m}^{3}$. The high variability in vesicularity controls the engineering properties of basaltic scoria. This variability stems from inherent differences in vesicularity, which control porosity, water absorption, and strength. The material of lower vesicularity will generally be denser and stronger, and therefore potentially of greater use in engineering [25].

2.1.3.1 Property of scoria The scoria aggregate (Fig. 4) obtained from the quarry didn't meet the code of requirements. As a result, it is blended to satisfy the ASTM C330 code of requirements. $10 \%$ and $13 \%$ of the sample mass with $1.18 \mathrm{~mm}$ and $0.3 \mathrm{~mm}$ fine scoria aggregates were added during scoria blending respectively and meet the requirement of ASTM standard as shown in Fig. 5.

The scoria used for the research has the following properties.

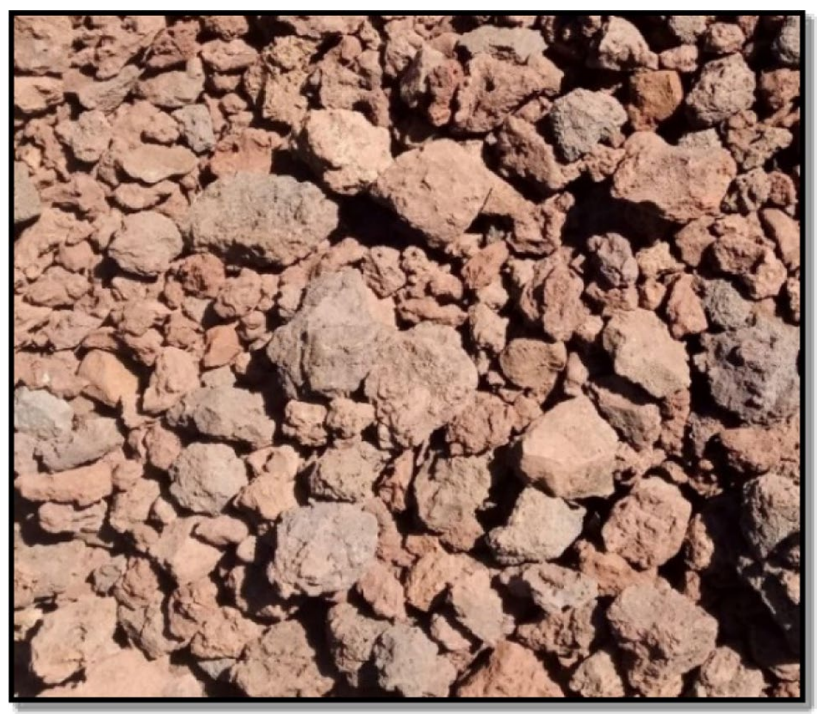

Fig. 4 Scoria aggregates

\begin{tabular}{ll}
\hline Fineness modulus & 2.91 \\
Unit weight & $1005 \mathrm{~kg} / \mathrm{m}^{3}$ \\
Specific gravity & 1.86 \\
Absorption & $7.2 \%$ \\
Free moisture content & $3.5 \%$ \\
Silt Content & $3.4 \%$ \\
Not presoaked before a mix & \\
\hline
\end{tabular}

\subsubsection{Property of coarse aggregate}

The strength of concrete depends mainly on the quality of the aggregates used. Well-graded crushed basaltic

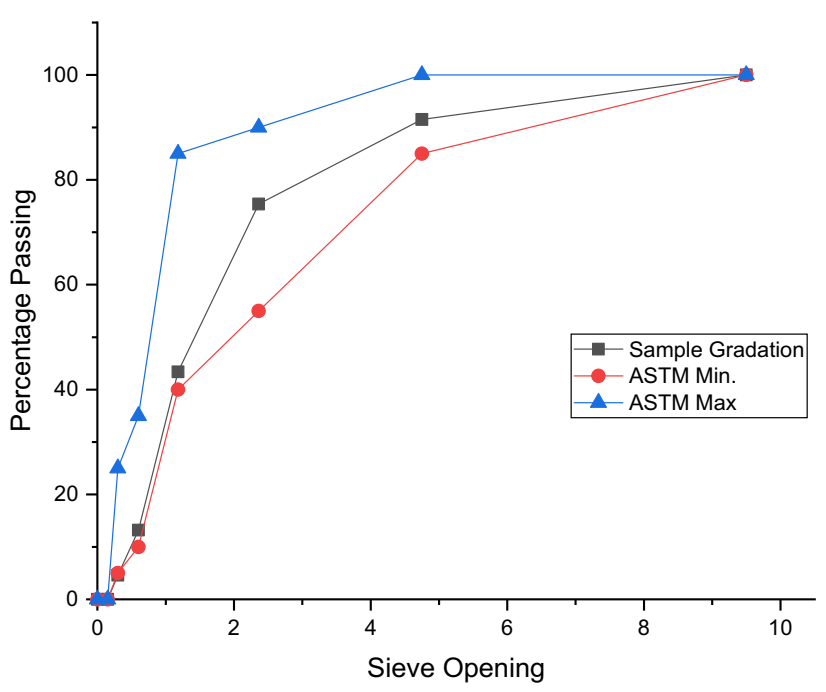

Fig. 5 Grading of scoria 
stone coarse aggregate was used and washed to make it free from dust and deleterious materials, which meet the requirements of ASTM standards. Figure 6 shows the gradation of coarse aggregate.

The coarse aggregate used for the study has the following properties.

\begin{tabular}{ll}
\hline Maximum size & $25 \mathrm{~mm}$ \\
Unit weight & $1495 \mathrm{~kg} / \mathrm{m}^{3}$ \\
Specific gravity & 2.84 \\
Absorption & $0.53 \%$ \\
Free moisture content & $0.77 \%$ \\
\hline
\end{tabular}

\subsubsection{Mix design}

Concrete having a compressive strength of $25 \mathrm{MPa}$ was used to perform the investigation. All concrete mixes were prepared as per $\mathrm{ACl} 211.1-91$. A total of 10 series of concrete mix (Table 1) presents the reference concrete proportion) prepared for a constant water-cement ratio of 0.49 and slump range between 75 and $100 \mathrm{~mm}$ (Recommended and used by, [9] for scoria since, it has greater absorption capacity than other fine aggregates due to its porosity and also used by, [26] for marble waste).

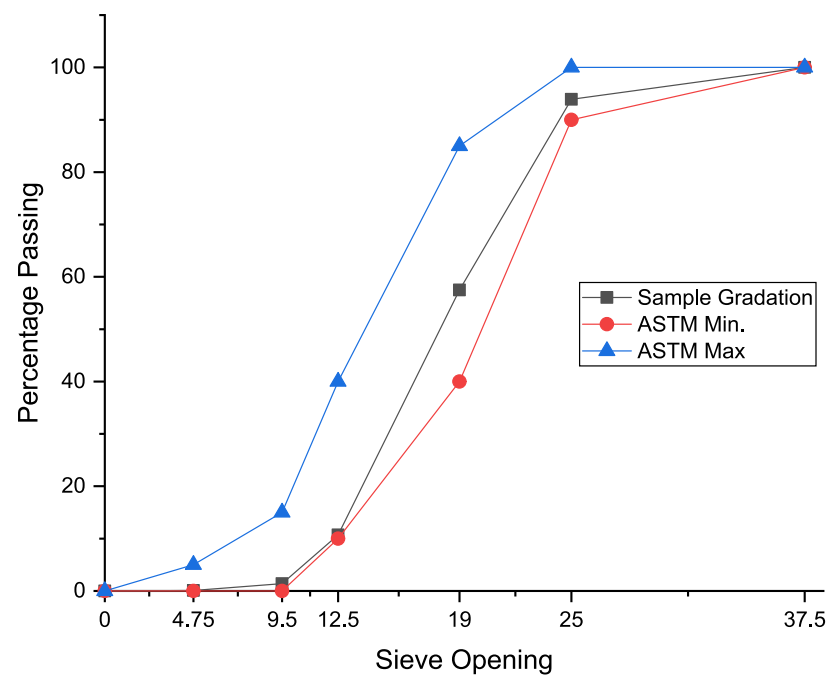

Fig. 6 Grading of coarse aggregate

\subsection{Methods}

The research was conducted at Bahir Dar University, Bahir Dar Institute of Technology (BIT) in a construction material laboratory. Concrete having a compressive strength of $25 \mathrm{MPa}$ was used. The materials used in the investigation were described concerning their source and physical properties but for marble waste and scoria, chemical analysis was conducted at the Ethiopian geological survey laboratory. The proportions of cement, water, and coarse aggregate were held constant in all the test mixes while the amount of scoria, marble, and fine aggregate was variable. A total of $90(150 \mathrm{~mm} \times 150 \mathrm{~mm} \times 150 \mathrm{~mm})$ concrete cubes and 9 specimens for each series of the mix were cast and tested for compressive strength test at 3, 7, and 28 days based on BS 1881-116 standard. A slump test was conducted for each mix as per ASTM C 143 to measure and determine the workability of the mix.

The type and method of test for coarse and fine aggregates are as per ASTM standards as they are presented in Table 2.

\subsubsection{Formulation of the combination method}

There are 10 different sets of mixes including the control mix (Table 3) used for investigations with a constant water-cement ratio of 0.49 and slump range between 75 and $100 \mathrm{~mm}$. Marble: scoria ratio of 2:1, 1:1, and 1:2 were used, and then the combined level of both marble waste and scoria increase from 33 to 67 to $100 \%$.

Table 2 Tests on aggregate and test methods

\begin{tabular}{|c|c|c|c|}
\hline \multirow[t]{2}{*}{ Types of Test } & \multicolumn{3}{|l|}{ Test methods } \\
\hline & $\begin{array}{l}\text { Coarse aggre- } \\
\text { gate }\end{array}$ & Marble and sand & Scoria \\
\hline $\begin{array}{l}\text { Moisture con- } \\
\text { tent }\end{array}$ & ASTM C 566 & ASTM C 566 & ASTM C 566 \\
\hline Gradation & ASTM C 136 & ASTM C 136 & ASTM C 330 \\
\hline Unit weight & ASTM C 29 & ASTM C 29 & ASTM C 29 \\
\hline $\begin{array}{l}\text { Specific gravity } \\
\text { and absorp- } \\
\text { tion }\end{array}$ & ASTM C 127 & ASTM C 128 & ASTM C 128 \\
\hline Silt content & - & ASTM C 117 & ASTM C 117 \\
\hline
\end{tabular}

Table 1 Reference concrete mix proportions

\begin{tabular}{lllrlrll}
\hline Mix & Per & Cement $(\mathrm{kg})$ & Water (lit) & $\begin{array}{l}\text { Coarse } \\
\text { aggregate } \\
(\mathrm{kg})\end{array}$ & Sand $(\mathrm{kg})$ & Scoria $(\mathrm{kg})$ & Marble $(\mathrm{kg})$ \\
\hline Mix 1 & $\mathrm{m}^{3}$ & 394 & 194.5 & 1032.5 & 798.5 & 0 & 0 \\
& Trial & 14.4 & 7.1 & 37.7 & 29.2 & 0 & 0 \\
\hline
\end{tabular}


Table 3 Proportioning and test specimens

\begin{tabular}{llll}
\hline Description & Sand (\%) & $\begin{array}{l}\text { Marble waste } \\
(\%)\end{array}$ & Scoria (\%) \\
\hline Mix 1 & 100 & 0 & 0 \\
Mix 2 & 67 & 11 & 22 \\
Mix 3 & 67 & 16.5 & 16.5 \\
Mix 4 & 67 & 22 & 11 \\
Mix 5 & 33 & 22.5 & 44.5 \\
Mix 6 & 33 & 33.5 & 33.5 \\
Mix 7 & 33 & 44.5 & 22.5 \\
Mix 8 & 0 & 33 & 67 \\
Mix 9 & 0 & 50 & 50 \\
Mix 10 & 0 & 67 & 33 \\
\hline
\end{tabular}

\subsubsection{Method of data analysis}

The data analysis was made with a series of steps. The first step is the chemical properties of marble waste and scoria, which tested at the Ethiopian Geological Survey laboratory were discussed and analyzed. The second step is the analysis of the test results of concrete, which is produced based on the conventional mix. The workability of fresh concrete and compressive strength of the hardened concrete analysis is made on the control mix and concrete having marble waste and scoria based on their proportioning. The third step is the cost comparison analysis. As an analysis tool for compressive strength test on harden concrete, factorial two way ANOVA with $R$ version 3.6.1 is used to determine the mix with a higher degree of significance and 0.05 confidence level is used for the statistical analysis and finally the sand replacement rates at which marble waste and scoria can be effectively substituted into concrete production from the series of mixes are determined.

\subsubsection{Concrete casting and cost comparison}

All ingredients of concrete mixes are measured by weight according to their proportions. The concrete production was made using a pan mixer of $0.38 \mathrm{~m}^{3}$ capacity. Based on the proportioning coarse aggregate, sand, scoria, marble waste and cement are dry mixed for $2 \mathrm{~min}$. After dry mixing, the specified quantity of water was then added, and the mixture subsequently mixed for another $4 \mathrm{~min}$. To test the workability of concrete a slump test was made by slump cone and fed directly into the cube molds and compacted by vibration for slumps less than $75 \mathrm{~mm}$ and by tamping for slumps greater than $75 \mathrm{~mm}$ and demolded after $24 \mathrm{hr}$. of casting and immersed into curing tank.

The material cost of produced concrete per unit volume was calculated for each proportion of concrete containing marble waste and scoria based on the current base price
Table 4 Chemical composition of marble waste and scoria

\begin{tabular}{|c|c|c|}
\hline \multirow[t]{2}{*}{ Parameters } & \multicolumn{2}{|l|}{ Tested samples } \\
\hline & Marble waste (\%) & Scoria (\%) \\
\hline $\mathrm{SiO}_{2}$ & 7.84 & 54.36 \\
\hline $\mathrm{Al}_{2} \mathrm{O}_{3}$ & $<0.01$ & 16.27 \\
\hline $\mathrm{Fe}_{2} \mathrm{O}_{3}$ & 0.32 & 11.02 \\
\hline $\mathrm{CaO}$ & 49.4 & 7.76 \\
\hline $\mathrm{MgO}$ & 0.6 & 5.44 \\
\hline $\mathrm{Na}_{2} \mathrm{O}$ & $<0.01$ & $<0.01$ \\
\hline $\mathrm{K}_{2} \mathrm{O}$ & 0.4 & 1.6 \\
\hline $\mathrm{MnO}$ & 0.04 & 0.16 \\
\hline $\mathrm{P}_{2} \mathrm{O}_{5}$ & $<0.01$ & 0.1 \\
\hline $\mathrm{TiO}_{2}$ & 0.03 & 0.62 \\
\hline $\mathrm{H}_{2} \mathrm{O}$ & 0.28 & 0.72 \\
\hline LOI & 40.23 & 1.78 \\
\hline $\mathrm{SO}_{3}$ & 0.6 & 0.89 \\
\hline
\end{tabular}

of materials from the local market within the city and compared with the cost of the reference or control mix.

\section{Results and discussion}

\subsection{Chemical characterization of marble waste and scoria}

The result of the chemical analysis of the marble waste and scoria sample are given in Table 4. The chemical analysis indicates that the major oxide of marble waste is $\mathrm{CaO}$ and $\mathrm{SiO}_{2}$ along with major loss on ignition (LOI). The major oxides of scoria are $\mathrm{SiO}_{2}, \mathrm{Al}_{2} \mathrm{O}_{3}, \mathrm{Fe}_{2} \mathrm{O}_{3}, \mathrm{CaO}$, and $\mathrm{MgO}$. Depending on the primary oxide composition, marble waste is classified as calcareous aggregate since its primarily composed of $\mathrm{CaO}$ whereas scoria is primarily composed of $\mathrm{SiO}_{2}$ and classified as siliceous aggregate. The presence of volcanic scoria leads to the disappearance of (calcium hydroxide) portlandite crystals and the appearance of the condensed type of $\mathrm{C}-\mathrm{S}-\mathrm{H}$ crystals due to the presence of $\mathrm{CaO}$ and $\mathrm{SiO}_{2}$. Condensed $\mathrm{C}-\mathrm{S}-\mathrm{H}$ fills the micropores, reduces the porosity, and consequently improves the impermeability and the compressive strength of concrete which is revealed by [24, 27]. Marble powder is a micro-fine filler; due to this filler effect, concrete strength is enhanced. The use of marble powder is more effective as a substitute for sand which is revealed by [28].

The presence of scoria improves the strength of concrete by creating condensed $\mathrm{C}-\mathrm{S}-\mathrm{H}$ gel with the presence of $\mathrm{CaO}$ and $\mathrm{SiO}_{2}$, whereas marble powder is microfine filler, by filler effect it improves the compressive strength of scoria according to those $[24,27,28]$ researchers, which is done on marble waste and scoria individually as 
cement and sand replacement. Since $\mathrm{CaO}$ and $\mathrm{SiO}_{2}$ are major cement making oxides different studies shows that, replacing marble waste and scoria individually as cement improve the compressive strength due to the presence of those cement making oxides produce additional C-S-H gel but in this study since marble waste and scoria used as a sand and the methodology of using marble and scoria as sand and cement is different so, it requires more advanced microstructure investigation to determine the extent of the effect of marble waste and scoria on compressive strength.

\subsection{Workability and compressive strength}

The summary of the slump and Average compressive strength test results are presented in Table 5. As shown on the table, the control mix shows better workability compared with all of the mixes. As the combined replacement rate of sand with marble waste and scoria increase from 0 to $33 \%$ the slump decreased by $30 \%(15 \mathrm{~mm})$ the reason behind is the increment of water demand due to the presence of marble waste and scoria. When the combined replacement rate of sand with marble waste and scoria increases from 33 to $67 \%$ the slump decreased by $6 \%$ (3 mm), since the replacement rate is significant the water content added to the concrete mix during adjustment also increases, which balance the workability of the mix. At $100 \%$ combined replacement rate of sand with marble waste and scoria there is a significant reduction of a slump by $60 \%$ ( $30 \mathrm{~mm}$ ) due to the significant increment of water demand at the full replacement of sand with marble waste and scoria This argument also revealed by [26] Moreover, to easily understand the difference, the result is shown graphically in Fig. 7 .

The compressive strength test result in Table 5 shows that, all concrete mixes made with partial replacement of sand with marble waste and scoria improve the compressive strength and achieved the target mean strength

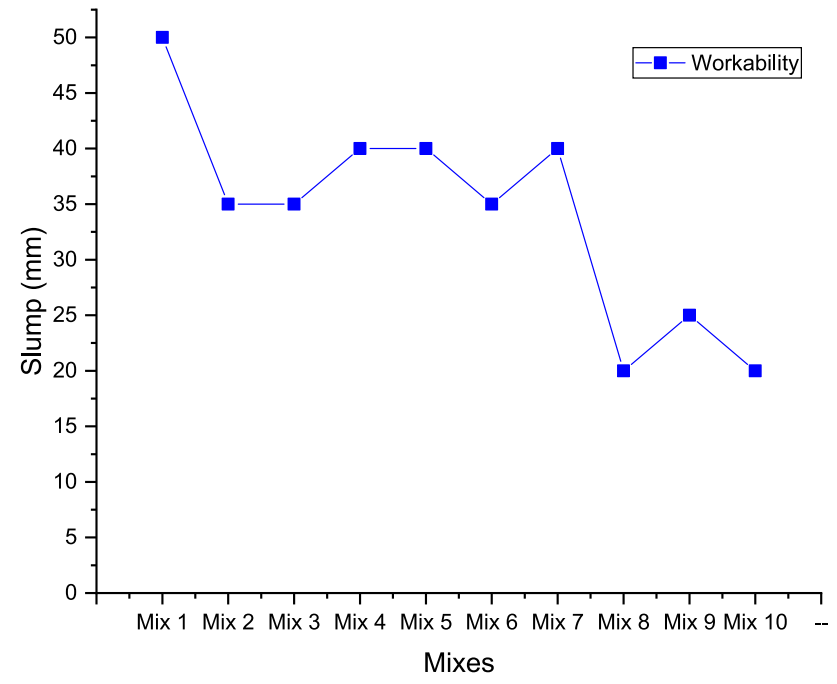

Fig. 7 The slump test result

except the control mix. As the combined ratio of marble waste and scoria increase from 0 to $33 \%$ for equal replacement ratio of marble waste and scoria, when the marble ratio is twice of the scoria and when the scoria ratio is twice of the marble the concrete strength increase by $22.8 \%$ (9.15 MPa), 29.1\% (12.7 MPa), and 11.2\% (3.89 MPa) respectively when compared to the control mix since the presence of marble waste improve the concrete strength as it is also revealed by [26].

When the partial replacement of sand with marble waste and scoria increased from 33 to $67 \%$, the concrete strength for all mix, improved by $27 \%(11.56 \mathrm{MPa}), 28.7 \%$ (12.5 MPa), 24.3\% (9.94 MPa) for the mix 5, mix 6 and mix 7 respectively when compared to the control mix. At $100 \%$, replacement of sand with marble waste, and scoria the strength is improved by $25 \%$ (10.3 Mpa), $25.4 \%$ (10.5 MPa), and $27.3 \%$ ( $11.67 \mathrm{MPa}$ ) for mix 8 , mix 9 and mix 10 respectively when compared to the control mix. However, the strength of concrete with a full replacement rate of sand
Table 5 Slump and average compressive strength test result

\begin{tabular}{lllll}
\hline Mixes & Slump $(\mathrm{mm})$ & \multicolumn{3}{l}{ Average compressive strength test result } \\
\cline { 3 - 5 } & & 3rd Day (MPa) & 7th Day (MPa) & 28th Day (MPa) \\
\hline Mix 1 (0M0S) & 50 & 19.22 & 25.78 & 31.01 \\
Mix 2 (11M22S) & 35 & 21.3 & 26.92 & 34.9 \\
Mix 3 (16.5M16.5S) & 35 & 23.53 & 32.52 & 40.16 \\
Mix 4 (22M11S) & 40 & 26.38 & 36.8 & 43.73 \\
Mix 5 (22.5M44.5S) & 40 & 26.4 & 38.33 & 42.57 \\
Mix 6 (33.5M33.5S) & 35 & 27.3 & 35 & 43.5 \\
Mix 7 (44.5M22.5S) & 40 & 23.88 & 35.52 & 40.95 \\
Mix 8 (33M67S) & 20 & 29.32 & 35.77 & 41.31 \\
Mix 9 (50M50S) & 25 & 30.05 & 37 & 41.55 \\
Mix 10 (67M33S) & 20 & 28.74 & 36.63 & 42.68 \\
\hline
\end{tabular}




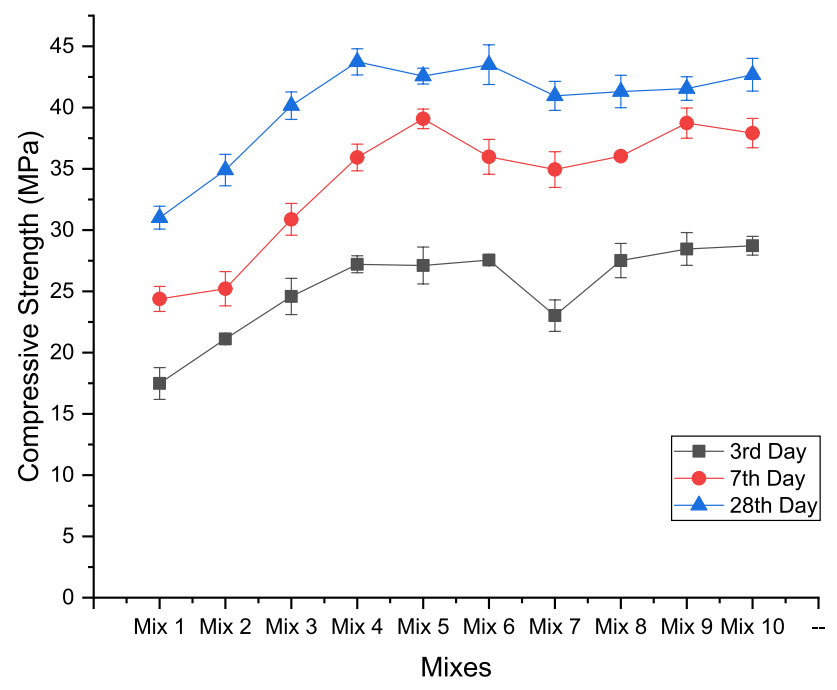

Fig. 8 Compressive strength test result

with marble waste and scoria is reduced when compared to the partial replacement. Moreover, to easily understand the difference the result is shown graphically in Fig. 8.

\subsection{Statistical analysis}

For this study, seven major hypotheses are made: Null hypothesis $\left(\mathbf{H}_{0}\right)$ :

$\boldsymbol{\mu}_{01}=$ Replacement of sand by marble waste doesn't affect the compressive strength of concrete.

$\boldsymbol{\mu}_{\mathbf{0 2}}=$ Replacement of sand by scoria doesn't affect the compressive strength of concrete.

$\boldsymbol{\mu}_{\mathbf{0 3}}=$ Age doesn't affect the compressive strength of concrete.

$\boldsymbol{\mu}_{\mathbf{0 4}}=$ Replacement of sand by marble waste and scoria doesn't affect the compressive strength of concrete.

$\boldsymbol{\mu}_{05}=$ Age and replacement of sand by marble waste doesn't affect the compressive strength of concrete.

$\boldsymbol{\mu}_{06}=$ Age and replacement of sand by scoria doesn't affect the compressive strength of concrete.

$\boldsymbol{\mu}_{\mathbf{0 7}}=$ Age and replacement of sand by marble waste and scoria doesn't affect the compressive strength of concrete.

\subsubsection{Significant factors affecting the compressive strength of concrete}

The main and interaction effect between the test subjects (dependent variable is compressive strength, whereas marble waste replacement rate, scoria replacement rate, and Age are independent variables) of the $R$ test result is presented in Table 6 .
Table 6 Main and interaction effect of $R$ test result

\begin{tabular}{lcrrll}
\hline & Df & Sum Sq & Mean Sq & F value & $\operatorname{Pr}(>F)$ \\
\hline Marble & 1 & 644.6 & 644.6 & 42.871 & $4.76 \mathrm{e}-09$ \\
Scoria & 1 & 102.2 & 102.2 & 6.799 & 0.01083 \\
Age & 1 & 2505.6 & 2505.6 & 166.639 & $2 \mathrm{e}-16$ \\
Marble:Scoria & 1 & 133.3 & 133.3 & 8.867 & 0.00382 \\
Marble:Age & 1 & 2.3 & 2.3 & 0.155 & 0.69499 \\
Scoria:Age & 1 & 7.5 & 7.5 & 0.498 & 0.48236 \\
Marble:Scoria:Age & 82 & 39.9 & 39.9 & 2.651 & 0.10730 \\
Residuals & 82 & 1232.9 & 15.0 & & \\
\hline
\end{tabular}

Based on Table 6 the main effects such as marble, scoria, and age have a significant effect on the compressive strength of concrete since the $p$ value is less than 0.05 for a $95 \%$ confidence interval, therefore the null hypothesis $\mu_{01}$, $\mu_{02}$, and $\mu_{03}$ are rejected. The interaction effect is not significant except the combined replacement rate of marble waste and scoria, which is 0.00382 less than 0.05 , therefore null hypothesis $\mu_{04}$ is rejected whereas, the decision is not rejecting null hypothesis $\mu_{05}, \mu_{06}$, and $\mu_{07}$ since the $p$ value is greater than 0.05 .

\subsection{Cost analysis}

The cost comparison only considers the cost of material and transportation other costs such as labor cost, equipment cost, profit, maintenance, and overhead costs assumed to be the same. The effect of replacement of sand by marble waste and scoria on the cost of concrete, which is expressed by cost per cubic meter of concrete, is assessed based on the material prices collected from most common sources and suppliers.

The partial replacement of sand with marble waste and scoria can save the cost of concrete up to $4.5 \%$ when compared to the control mix. According to the cost analysis as the percentage replacement rate of marble waste increase, the cost also increases the reason behind is the abundance of marble is low around Bahir Dar, Ethiopia and there is only one marble factory in Bahir Dar which, raise the cost of marble waste. However, scoria is highly abundant in and around Bahir Dar and its cost is five times lower than that of sand. Moreover, to easily understand the difference the result is shown graphically in Fig. 9.

\subsection{Qualitative optimization of replacement of sand with marble waste and scoria}

The basic merit of good mix design is to produce concrete that satisfies the three basic requirements, which are; workability, strength, and cost. As it's observed in the previous sections, replacement of sand with marble 


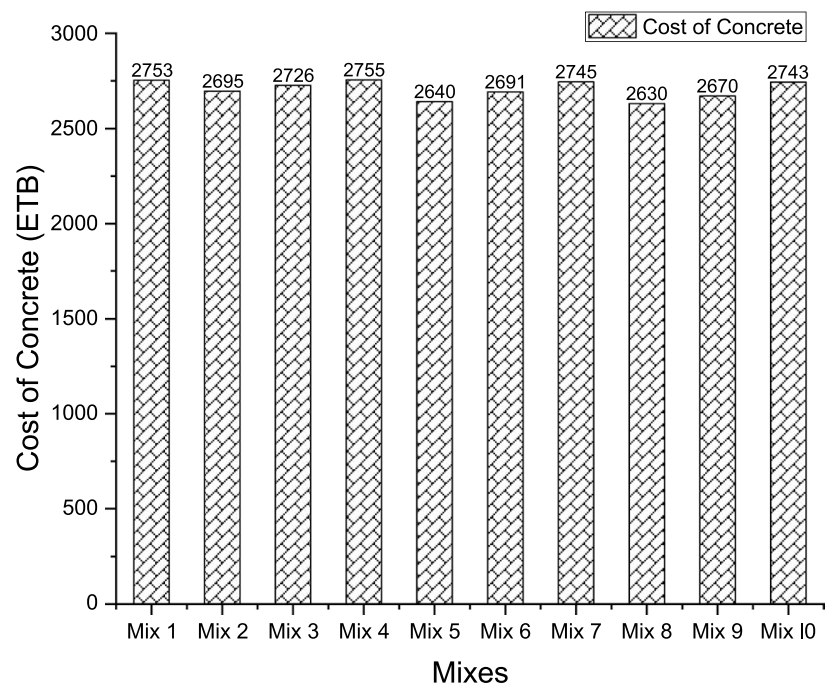

Fig. 9 Cost comparison

waste and scoria has a significant negative effect on the workability of fresh mix, a positive effect on the strength of hardened concrete, and a non-significant effect on the cost when compared to strength and workability. The optimum or effective substitution of concrete containing marble waste and scoria is selected depending on the percentage increase/decrease of strength, cost, and workability as shown in Fig. 10.

Based on Fig. 10 tradeoffs are made between strength, workability, and cost, mix 1 has a $0 \%$ increase/ decrease since it's a reference mix. Mix 2 and mix 3 have less increase in strength when compared to other mixes. Mix 4, Mix 5, and Mix 6 have a better increase in strength and less decrease in workability; mix 5 has an economic benefit. Mix 8, Mix 9, and Mix 10, the strength is gradually decreasing and there is a significant loss in slump whereas Mix 8 has a better economic benefit when compared to other mixes.

\subsection{Concrete weight}

The experimental result reveals that as the combined level of marble waste and scoria increase the weight of concrete decreases up to $5 \%$ as presented in Fig. 11 . The weight reduction directly related to scoria, which is a natural lightweight aggregate that can significantly reduce the dead weight of concrete by decreasing the cross-section of structural members and the amount of reinforcing steel and reduce the cost of producing artificial aggregates for concrete production.[29].

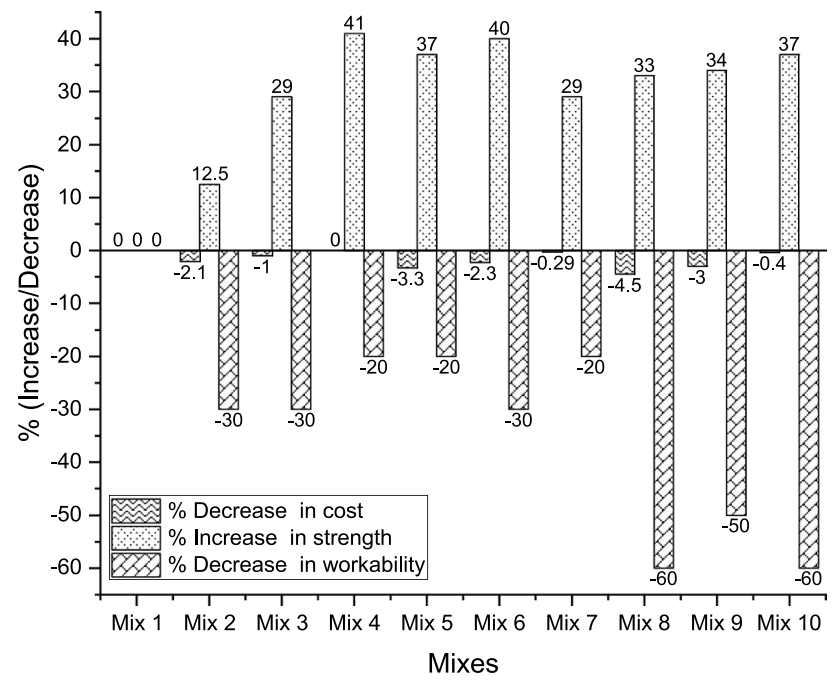

Fig. 10 Percentage increase/decrease in strength, workability, and cost

\section{Conclusions}

Based on experimental results, the following conclusions are drawn concerning marble waste and scoria added concrete.

1. The partial replacement of sand with marble waste and scoria up to $67 \%$ can improve the compressive strength of concrete up to $30 \%$, However, further, an increase in replacement of marble waste and scoria decrease the compressive strength. Whereas, when

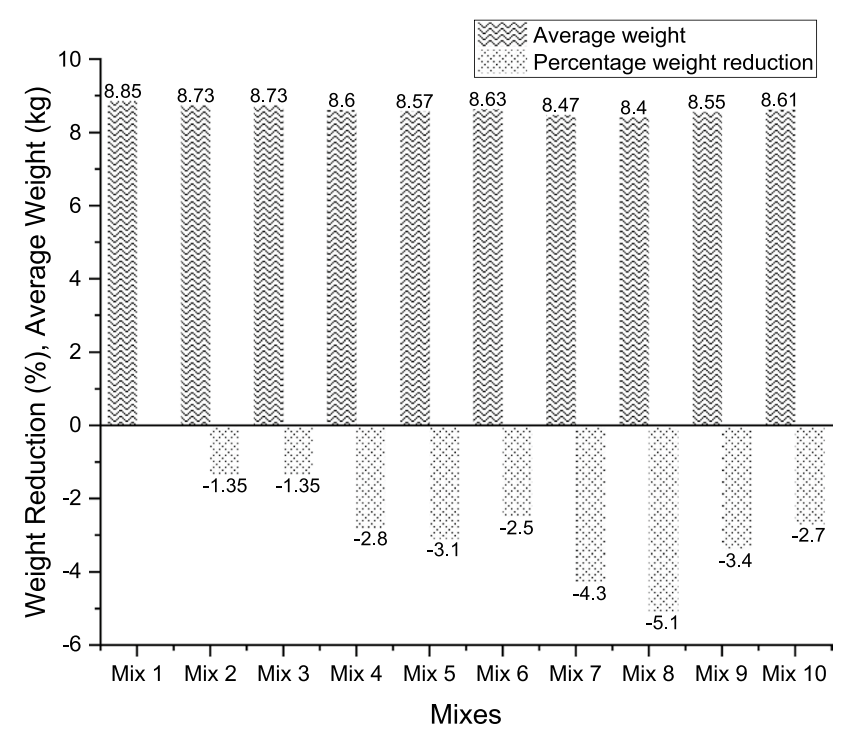

Fig. 11 Concrete weight reduction 
the combined replacement rate of marble waste and scoria increase the workability of concrete decrease.

2. The cost analysis also shows that replacing sand with marble waste and scoria can save up to $4.5 \%$ of the total cost of concrete than the conventional concrete.

3. The combined replacement rate of $67 \%$ marble waste and scoria, which is $22.5 \%$ marble waste and $44.5 \%$ scoria will give effective and optimum sand substitution rate from strength, workability, and cost point of view for $\mathrm{C}-25,0.49$ water to cement ratio.

4. As the combined level of marble waste and scoria increase, the weight of concrete decreases up to 5\% without compromising the compressive strength of concrete.

This research should be supplemented by the following studies:

- The effect of partial replacement of sand with marble waste and scoria on the durability property of concrete.

- The potential of partial replacement of sand with marble waste and scoria for high strength concrete.

- The effect of the partial replacement of sand with marble waste and scoria by incorporating admixture should be studied.

- The extent at which $\mathrm{CaO}, \mathrm{SiO}_{2}$, and other cement making oxides affect the compressive strength should be studied

\section{Compliance with ethical standards}

Conflict of interest The authors declare that they have no conflict interests.

\section{References}

1. Ganesh Prabhu G, Hyun JH, Kim YY (2014) Effects of foundry sand as a fine aggregate in concrete production. Constr Build Mater 70:514-521. https://doi.org/10.1016/j.conbuildma t.2014.07.070

2. Mehta PK, Monteiro PJM (2006) Concrete: microstructure, properties, and materials, 3rd edn. McGraw-Hill. https://doi. org/10.1036/0071462899

3. Denamo A (2005) Handling of concrete making materials in the ethiopian construction industry. Addis Ababa University, Addis Ababa

4. Tugrul Tunc E (2019) Recycling of marble waste: a review based on strength of concrete containing marble waste. J Environ Manag 231:86-97. https://doi.org/10.1016/j.jenvm an.2018.10.034

5. Thakur AK, Pappu A, Thakur VK (2018) Resource efficiency impact on marble waste recycling towards sustainable green construction materials. Curr Opin Green Sustain Chem 13:91101. https://doi.org/10.1016/j.cogsc.2018.06.005

6. Aliabdo AA, Abd Elmoaty AEM, Auda EM (2014) Re-use of waste marble dust in the production of cement and concrete. Constr Build Mater 50:28-41. https://doi.org/10.1016/j.conbuildma t.2013.09.005

7. Arel HS (2016) Recyclability of waste marble in concrete production. J Clean Prod 131:179-188. https://doi.org/10.1016/j.jclep ro.2016.05.052

8. Tayeh BA (2018) Investigation of the effect of marble, timber, and glass powder as a partial replacement of cement. J Civ Eng Constr 7(02):63-71

9. Hossain KMA (2006) Blended cement and lightweight concrete using scoria: Mix design, strength, durability, and heat insulation characteristics. Int J Phys Sci 1(1):5-16. https://doi.org/10.5897/ IJPS.9000099

10. Negussie T, Taye $S$ (1984) Scoria sand replacement in structural concrete. J Educ Assess Eval Account 6:27-32

11. Dinku A (2005) The need for standardization of aggregates for concrete production in ethiopian construction. Third international conference on development studies in Ethiopia, Addis Ababa, Ethiopia, pp 1-15

12. Taylor WH (1977) Concrete technology and practice, 4th edn. McGraw-Hill, Sydney

13. Shetty MS (2009) Concrete technology (theory and practice). Eng Mater. https://doi.org/10.1017/CBO9781107415324.004

14. John M (2007) Geology of sand dunes: white sands national monument. New Mexico -United States

15. Honnun (2004) Production and utilization of manufactured sand for concrete purpose. Nordic atlantic cooperation report

16. Kosmatka SH, Kerkhoff B, Panarese WC (2015) Design and control of concrete mixtures. ASTM Stand Book. https://doi. org/10.1520/C0127-12.1

17. Neville AM (2011) Properties of concrete fifth edition. In: Mulvaney D (ed) Green technology an A-to-Z guide. SAGE Publication, California

18. Kraus EH (1959) Mineralogy: an introduction to the study of minerals and crystals. McGraw-Hill, New York

19. United Nations Environment Program (UNEP). (2014). Sand, rarer than one thinks. United Nations Environment Program (UNEP). 2012(March), 1-15. https://wedocs.unep.org/bitstream/handl e/20.500.11822/8665/GEAS_Mar2014_Sand_Mining.pdf?seque nce $=3$ \&isAllowed $=y$

20. Jones $G$ (2009) Mineral sands: an overview of the industry. International mining geology conference 2009

21. Sreenivasa G (2019) Use of manufactured sand in concrete and construction an alternate to river sand. Retrieved from NBM\&CW infra construction and equipment: https://www.nbmcw.com/ articles/concrete/28675-use-of-manufactured-sand-inconcrete -and-construction-an-alternate-to-river-sand.html

22. Berhanu N (2018) Utilization of waste marble powder as partial replacement of cement in HCB production. Addis Ababa University School of Graduate Studies, Addis Ababa

23. Nemerow NL, Agardy FJ, Sullivan P, Salvato JA (2009) Environmental engineering: environmental health and safety for municipal infrastructure, land use, and planning, and industry: sixth edition. Wiley, New Jersey. https://doi.org/10.1002/9780470432 822

24. Al-Swaidani AM (2018) Volcanic scoria as cement replacement. In: Aiello G (ed) Volcanoes - geological, and geophysical setting, theoretical aspects and numerical modeling, application to industry and their impact on the human health. IntechOpen, pp 11-37. https://doi.org/10.5772/intechopen.77970. Available from: https://www.intechopen.com/books/volcanoes-geolo gical-and-geophysical-setting-theoretical-aspects-and-numer 
ical-modeling-applications-to-industry-and-their-impact-onthe-human-health/volcanic-scoria-as-cement-replacement

25. Ethiopian Road Authority (2018) Guideline for the use of cinder gravels in pavement layers for low volume roads (Final Draft, Issue February)

26. Hebhoub H, Aoun H, Belachia M, Houari H, Ghorbel E (2011) Use of waste marble aggregates in concrete. Constr Build Mater 25(3):1167-1171. https://doi.org/10.1016/j.conbuildma t.2010.09.037

27. Fares G, Alhozaimy A, Alawad OA, Al-Negheimish A (2016) Evaluation of powdered scoria rocks from various volcanic lava fields as a cementitious material. J Mater Civ Eng 28(3):1-9. https:// doi.org/10.1061/(ASCE)MT.1943-5533.0001428
28. Ashish DK (2018) Feasibility of waste marble powder in concrete as partial substitution of cement and sand amalgam for sustainable growth. J Build Eng 15:236-242. https://doi.org/10.1016/j. jobe.2017.11.024

29. Yohannes M (2015) Investigation on the suitability of pumice and scoria aggregates in ribbed-slab construction. J Civ Eng Res 5(4):75-82. https://doi.org/10.5923/j.jce.20150504.01

Publisher's Note Springer Nature remains neutral with regard to jurisdictional claims in published maps and institutional affiliations. 